Trinity University

Digital Commons@ Trinity

Library Faculty Research

Coates Library

2017

\title{
IMSLP/Petrucci Music Library
}

Colleen Hoelscher

TrinityUniversity, choelsch@trinity.edu

Follow this and additional works at: https://digitalcommons.trinity.edu/lib_faculty

Part of the Library and Information Science Commons

\section{Repository Citation}

Hoelscher, C. (2017) IMSLP/Petrucci music library. Reference Reviews, 31(7), 26-27. doi: 10.1108/RR-05-2017-0119

This Post-Print is brought to you for free and open access by the Coates Library at Digital Commons @ Trinity. It has been accepted for inclusion in Library Faculty Research by an authorized administrator of Digital Commons @ Trinity. For more information, please contact jcostanz@trinity.edu. 
International Music Score Library Project/Petrucci Music Library.

URL: http://imslp.org

Last visited May 2017

Gratis, but with some restrictions; individual and corporate subscriptions available

Keywords: Music, Online databases, Music scores

The International Music Score Library Project (IMSLP), also known as the Petrucci Music Library, is a crowdsourced database of public domain music scores. Driven by a belief that "music should be something that is easily accessible to everyone," the site was created in 2006 with a goal of creating an exhaustive collection of music scores that are not under copyright. Today, over 390,000 scores are freely available to download from IMSLP, representing approximately 119,000 works by over 15,000 composers.

Regular users of Wikipedia will find the IMSLP/Petrucci Music Library, a wiki-style website, easy to navigate. The site uses Google for its internal search engine, providing most internet users with a familiar and comfortable interface, as well as reliable search results. Users can also browse by composer name or nationality, time period, instrumentation, genre, and language.

IMSLP operates on a subscription-based model; non-subscribers are shown web banner ads, though these are fairly unobtrusive and do not significantly impede use of the resource. The site also imposes a fifteensecond delay on PDF downloads for non-subscribers. Frequent users should consider an individual subscription (\$22 per year), which eliminates these encumbrances. Institutional memberships are available on a sliding scale, with pricing based upon the number of users and other factors.

The digitized scores in the IMSLP/Petrucci Music Library come from a variety of sources, including the Bach-Gesellschaft Ausgabe, the Sibley Music Library at the University of Rochester, and the Bibliothèque nationale de France. To date, the oeuvres of many prominent composers have been collected, including the complete works of Johann Sebastian Bach, Ludwig van Beethoven, Joseph Haydn, Franz Schubert, and Claude Debussy, among others. A comparison by the reviewer of major works in the public domain found that the holdings in IMSLP and Alexander Street's Classical Scores Library (a ProQuest database available for purchase or subscription) overlapped with very few exceptions.

The IMSLP/Petrucci Music Library relies on wiki editing, meaning any user can contribute or edit the entries. This introduces the possibility of factual errors or inaccuracies. The site does, however, require contributors to create an account, and a robust team of volunteers reviews and corrects contributions. By its very nature, a crowdsourced resource like this can have uneven distribution of content; some artists' works are thoroughly represented, while the works of other composers may be spotty. There is relatively little content from the twentieth century, for example, owing to the site's strict copyright review policy. Works must be in the public domain or made available via a Creative Commons license, and all submissions are checked by three reviewers to ensure compliance. Users looking for more recent works would be better served by a purchased database, such as Alexander Street’s Classical Scores Library.

International Music Score Library Project's primary purpose is to make the digital sheet music of classic works freely available to all, but the site also doubles as a reference tool for music researchers. For example, different arrangements of the same work appear together on the same page, allowing users to easily compare them. Many of the entry pages for sheet music publishers include information about plate numbers, publication dates, and locations, providing hard-to-find data that researchers can use to identify or date sheet music. Like any wiki-style encyclopedia, however, users should note that these entries are not authoritative and may be incomplete. 
Sheet music can be an extremely expensive purchase for both libraries and musicians. Though its content is limited by strict copyright policies, the IMSLP/Petrucci Music Library is a robust collection of public domain music that continues to grow. Libraries--particularly ones that cannot afford a collection like the Alexander Street Classical Scores Library--should promote this free resource to patrons in search of sheet music.

\section{Colleen Hoelscher}

Special Collections Librarian, Coates Library

Trinity University, San Antonio, Texas, USA 